\title{
MENINGKATKAN KEMAMPUAN BAHASA INGGRIS ANAK DAN REMAJA PRA-SEJAHTERA UNTUK MENDUKUNG KEGIATAN PARIWISATA SITU LENGKONG PANJALU
}

\author{
R. Bunga Febriani*, Andi Rustandi², Bambang Ruby Sugiarto ${ }^{3}$ \\ Universitas Galuh Ciamis \\ *Email: bunga.febriani@gmail.com
}

\begin{abstract}
ABSTRAK
Penelitian ini bertujuan untuk meningkatkan kemampuan bahasa Inggris anak dan remaja pra-sejahtera untuk mendukung kegiatan pariwisata Situ Lengkong Panjalu melalui pelatihan bahasa Inggris untuk pariwisata. Kegiatan ini dilaksanakan sebanyak 6 sesi dalam waktu 3 bulan dengan metode praktik secara langsung, demonstrasi, simulasi, dan bermain peran secara berkelompok. Sebanyak 8 materi disajikan mengenai beberapa ungkapan, informasi, dan praktik komunikasi dalam Bahasa Inggris yang umum dan lazim digunakan di bidang pariwisata. Secara keseluruhan, kegiatan ini berjalan dengan baik. Peserta mampu mengikuti dan menampilkan demonstrasi secara langsung terkait materi yang diberikan. Walaupun masih terjadi kesalahan dalam hal pengucapan (pronunciation) dan peserta kegiatan masih perlu dorongan untuk lebih percaya diri dalam berbahasa Inggris. Di akhir kegiatan, diharapkan para peserta mendapatkan pengalaman belajar yang dapat menjadi salah satu modal bagi mereka untuk ikut bersaing di era industri 4.0 yang secara global menuntut kecakapan berkomunikasi dalam bahasa Inggris.
\end{abstract}

Kata Kunci: Bahasa Inggris, pariwisata, Anak dan Remaja, Pra-sejahtera

\section{PENDAHULUAN}

Di era revolusi industri 4.0 saat ini, bahasa Inggris diperlukan dalam banyak aspek kehidupan masyarakat sehari-hari. Selain para praktisi, masyarakat umum pun perlu untuk menguasai bahasa internasional ini. Bahasa Inggris sebagai salah satu bahasa internasional, penting untuk dikuasai, tidak hanya oleh para praktisi di bidangnya, tetapi juga oleh masyarakat umum, dalam hal ini khususnya untuk masyarakat yang tinggal di kawasan industri pariwisata.

Penguasaan bahasa Inggris bagi masyarakat di kawasan wisata memiliki beberapa peranan. Peranan-peranan tersebut diantaranya untuk promosi wisata ke luar negeri, untuk memberikan pelayanan reservasi dan akomodasi pemandu saat memandu wisatawan luar negeri (Setyanto, 2012). Kemudian, bahasa Inggris sebagai bahasa internasional bisa menjembatani komunikasi yang interaktif antara masyarakat lokal dan pengunjung yang berasal dari luar negeri (Aulia et al, 2017). Oleh karena itu, penguasaan bahasa Inggris dapat mendukung komunikasi niaga, dan juga memberikan informasi positif tentang objek wisata itu sendiri.

Pembatasan objek penelitian ini berbekal pada pertimbangan bahwa anak dan remaja cenderung lebih mudah untuk mempelajari bahasa asing dibandingkan dengan orang dewasa (Cameron, 2001; Shipton, 2006). Anak dan remaja dari keluarga pra-sejahtera dijadikan sebagai fokus penelitian dengan pertimbangan bahwa meningkatnya kemampuan mereka dalam berbahasa Inggris dapat mendukung dan memajukan taraf hidup mereka. 
Meningkatkan Kemampuan Bahasa Inggris Anak dan Remaja Pra-Sejahtera Untuk Mendukung Kegiatan Pariwisata Situ

Salah satu model pengentasan kemiskinan yang terbukti efektif di banyak negara berkembang adalah mengintegrasikan masyarakat miskin dalam industri pariwisata (Ashley, 2000; Cattarinich, 2001). Oleh karena itu, kegiatan ini diharapkan bisa menjadi salah satu solusi kemiskinan karena pariwisata merupakan sektor penting dibidang ekonomi Indonesia. Penelitian ini berfokus pada peningkatan kemampuan bahasa Inggris anak dan remaja prasejahtera di kawasan pariwisata Situ Lengkong Kecamatan Panjalu, Kabupaten Ciamis.

\section{BAHAN DAN METODE}

Sasaran kegiatan pengabdian kepada masyarakat ini adalah 40 orang anak dan remaja di sekitar kawasan pariwisata Situ Lengkong kecamatan Panjalu, Kabupaten Ciamis. Kegiatan ini dilaksanakan sebanyak 6 sesi dalam waktu 3 bulan dengan metode praktik secara langsung, demonstrasi, simulasi, dan bermain peran secara berkelompok. Sebanyak 8 materi disajikan mengenai beberapa ungkapan, informasi, dan praktik komunikasi dalam Bahasa Inggris yang umum dan lazim digunakan di bidang pariwisata.

\section{HASIL DAN PEMBAHASAN}

Berdasarkan hasil pengumpulan data dari kegiatan pelatihan bahasa Inggris untuk pariwisata bagi anak dan remaja pra-sejahtera di kawasan wisata Situ Lengkong Kecamatan Panjalu kabupaten Ciamis, dapat digambarkan sebagai berikut:

a. Peserta mampu memahami dan mengenal kosakata bahasa Inggris tentang ungkapanungkapan sapaan (greetings and other useful phrases)

Para peserta mampu memahami ungkapan-ungkapan sapaan dalam bahasa Inggris yang umum dipergunakan khususnya di dalam dunia pariwisata dan mendemonstrasikannya, diantaranya: sapaan selamat pagi, selamat siang, selamat sore, sapaan kabar, dan ungkapan perpisahan dalam bahasa Inggris seperti; Hi. Hello, good morning, good afternoon, good evening, how are you?, I'm fine thanks, and you?, excuse me, please, thank you, good bye, good night, etc.

b. Peserta mampu memahami dan mengenal kosakata bahasa Inggris tentang alam yang berkaitan dengan wisata situ Panjalu (in the country side, the natural world)

Para peserta mampu memahami kosakata bahasa Inggris yang berhubungan dengan alam dan lingkungan sekitar khususnya yang berhubungan dengan pariwisata situ Panjalu dan melakukan simulasi di alam terbuka, diantaranya: kosakata tentang alam dan lingkungan, pekerjaan, kehidupan dan suasana disekitarnya, nama-nama tumbuhan serta binatang yang ada disekitar daerah pariwisata dalam bahasa Inggris seperti; things we can see in the 
countryside, lake, mountains, forest, island, village, things to do in the countryside, picnic, eating out in nature, the natural world, etc.

c. Peserta mampu memahami dan mengenal kosakata bahasa Inggris tentang makanan dan minuman/kuliner (food and beverage)

Para peserta mampu memahami kosakata bahasa Inggris tentang makanan dan minuman/kuliner khususnya yang berhubungan dengan pariwisata situ Panjalu dan bermain peran, diantaranya: kosakata tentang nama-nama buah-buahan, sayuran, makanan, dan minuman yang ada di sekitar daerah pariwisata dalam bahasa Inggris seperti; fruit, banana, pineapple, vegetables, carrot, mushrooms, aubergine, potato, cucumber,onion, garlic, rice, meat, fish, lobster, shrimp, tea, coffee, milk, juice, etc.

d. Peserta mampu memahami dan mengenal kosakata bahasa Inggris tentang uang (money) Para peserta mampu memahami kosakata bahasa Inggris tentang uang dan melakukan simulasi dan bermain peran, diantaranya: kosakata tentang jenis uang kertas dan koin, dan ungkapan-ungkapan yang berhubungan dengan uang dalam bahasa Inggris seperti; money, notes and coins, currency, common verbs are used, spend, pay, cost, charge, lend, borrow, free, cheap, reasonable, expensive, etc.

e. Peserta mampu memahami dan mengenal kosakata bahasa Inggris tentang jual beli (shops and shopping)

Para peserta mampu memahami kosakata dan ungkapan-ungkapan bahasa Inggris tentang jual beli dan melakukan simulasi dan bermain peran, diantaranya: kosakata tentang jenis pertokoan, dan ungkapan-ungkapan yang berhubungan dengan jual beli dalam bahasa Inggris seperti; gift shop, mini market, traditional market, can I help you? How much does it cost? can I try it on? Would you like a bag? Can I pay by credit card? Cash only, I don't have any change, etc.

f. Peserta mampu memahami dan mengenal kosakata bahasa Inggris tentang cuaca, pemandangan alam, dan liburan (weather and sightseeing holiday)

Para peserta mampu memahami kosakata dan ungkapan-ungkapan bahasa Inggris tentang cuaca, pemandangan alam, liburan dan melakukan simulasi dan bermain peran, diantaranya: kosakata tentang jenis-jenis cuaca dan ungkapan-ungkapan yang berhubungan dengan cuaca, pemandangan alam, kegiatan wisata/wisatawan dalam bahasa Inggris seperti; sun, sunny, rain, rainy, wind, windy, it's a lovely weather today, isn't it? It's very cold here, look around, take photographs, buy souvenirs, get lost, go out, have a good time, nice place to stay, interesting places, historical monuments, etc. 
Meningkatkan Kemampuan Bahasa Inggris Anak dan Remaja Pra-Sejahtera Untuk Mendukung Kegiatan Pariwisata Situ Lengkong Panjalu

R. Bunga Febriani, Andi Rustandi, Bambang Ruby Sugiarto

\section{KESIMPULAN DAN SARAN}

\section{Kesimpulan}

Kegiatan ini cukup memberikan manfaat dan pengetahuan bagi para peserta pelatihan, dalam hal ini anak dan remaja yang berasal dari keluarga pra-sejahtera di kawasan wisata situ Lengkong Panjalu. Walaupun masih diperlukan pelatihan yang lebih komprehensif tentang cara pengucapan kata dan ungkapan bahasa Inggris, para peserta sudah cukup mendapatkan wawasan dan pengetahuan tentang bahasa Inggris untuk kebutuhan pariwisata. Kegiatan pelatihan ini diharapkan agar para peserta mendapatkan pengalaman belajar yang akan menjadi salah satu modal bagi mereka untuk ikut bersaing di era industri 4.0 yang secara global menuntut kecakapan berkomunikasi dalam bahasa Inggris.

\section{Saran}

Mengingat cakupan yang luas tentang topik bahasa Inggris untuk kebutuhan pariwisata dan juga waktu yang tersedia, diharapkan pemerintah dan pihak terkait untuk bisa membuka pelatihan bahasa Inggris secara berkelanjutan, khususnya untuk kebutuhan pariwisata bagi anak dan remaja pra-sejahtera di situ Lengkong Panjalu, sehingga mereka akan lebih percaya diri dalam komunikasi bahasa Inggris.

\section{DAFTAR PUSTAKA}

Ashley, Caroline. (2000). The Impact of Tourism on Rulal Livehoods: Namibia's Experience. London. Chameleon Press.

Aulia, Vivi et.al. (2017). Pelatihan Penggunaan Bahasa Inggris untuk Pariwisata (English for Tourism) Bagi Siswa SMKN 4 Banjarmasin. Jurnal Pengabdian Kepada Masyarakat.1 (1) 2017.

Cameron, Lynne. (2001). Teaching Languages to Young Learners. Cambridge. Cambridge University Press.

Cattarinich, Xavier .(2001). Pro-poor Tourism Initiatives in Developing Countries : Analysis of secondary case studies, PPT Working Papner o. 8, Department of Sociology, University of Alberta, Canada.

Cresswell, J. W. (1994). Research Design Qualitative and Quantitative Approaches. London. Sage Publications.

Dinas Pariwisata Kabupaten Ciamis. (2018). Situ Lengkong Panjalu. (online). Tersedia: https://dispar.ciamiskab.go.id/2017/04/12/situ-lengkong-panjalu/ (9 Desember 2018).

Dinas Pariwisata dan Kebudayaan Provinsi JABAR. (2018). Situ Lengkong Panjalu. (online). Tersedia: http://www.disparbud.jabarprov.go.id/wisata/dest-det.php?id=21\&lang=id (9 Desember 2018).

Galela, Dolfina (2014). Peranan Bahasa Inggris Di Bidang industri Pariwisata Di Tobelo. Jurnal Elektronik Fakultas Sastra Universitas Sam Ratulangi Vol 1, No 01 (2014).

McCarthy, Michael \& O'dell, Felicity. (1999). English Vocabulary in Use: Elementary. Cambridge. Cambridge University Press. 
McCarthy, Michael \& O'dell, Felicity. (2002). English Vocabulary in Use: UpperIntermediate. Cambridge. Cambridge University Press.

Kompas (2018). www.edukasi.kompas.com (online).

Kuncoro, Mudrajat (2006). Ekonomi Pembangunan: Teori, Masalah dan Kebijakan. Yogyakarta: UPP STIM YKPN

Nugroho, Heru (1999). Kemiskinan dan Kesenjangan di Indonesia: Kemiskinan, Ketimpangan dan Pemberdayaan. Yoyakarta: Adtya Media.

Redman, Stuart. (1997). English Vocabulary in Use: Pre-Intermediate and Intermediate. Cambridge. Cambridge University Press.

Setyanto, Aji. (2012). Pentingnya Penguasaan Bahasa dan Budaya Asing Sebagai Pendukung Utama Sektor Pariwisata. Tersedia: http://fib.ub.ac.id/wrp-con/uploads/JournalPariwisata-_Aji-Setyanto_-Pentingnya-Penguasaan-Bahasa-dan-Budaya-Asing.pdf

Shipton, I., Mackenzie, A.S., (2006). The Child as a Learner. Shipton J., \& Council.

Tempo.Co (2018) tersedia: https://travel.tempo.co/read/1139099/pertumbuhan-pariwisataindonesia-peringkat-9-di-dunia/full\&view $=\mathrm{ok}$

Tourism Indonesia (2018). Tersedia: http://wikipedia.org/TourismIndonesia 